\title{
Social Worker in Schools in High School Students
}

\author{
Daraha Kanlaya \\ Civic Women Prince of Songkla, Pattani Campus, Hat Yai, Thailand \\ Email: dkallaya2500@gmail.com
}

How to cite this paper: Kanlaya, D. (2021). Social Worker in Schools in High School Students. Open Journal of Social Sciences, 9, 541-554.

https://doi.org/10.4236/jss.2021.99039

Received: March 26, 2021

Accepted: September 24, 2021

Published: September 27, 2021

Copyright $\odot 2021$ by author(s) and Scientific Research Publishing Inc.

This work is licensed under the Creative

Commons Attribution International

License (CC BY 4.0).

http://creativecommons.org/licenses/by/4.0/

\begin{abstract}
School social work services were now being requested throughout the community in the United States in response to a changing social and educational climate (Allen-Meares, 1987; Allen-Meares et al., 1996). The social workers would prefer to solve the psychosocial aspects among high school students to use the internet in Pattani. Currently, social workers in Thailand have not been considered to help schools deal with high school students who are facing Psychosocial Aspects and Academic Performance. The finding of the interviews and focus group discussions for and ongoing study that the internet is both positive and negative. The community recommends, that including the students, the school directors, school teachers, the policemen, the parents, the internet owner cafes, the community were explored. Their responses in the interviews are discussed against the issues pertaining to social well-being and the use of internet among the high school students in Pattani. There is a general consensus among those interviewed and focus group discussion that it is necessary to have social workers in school in Pattani. School social workers can play a role in helping high school students use the internet appropriately and they can be more effective in solving problems that arose from internet use among high school students.
\end{abstract}

\section{Keywords}

School Social Worker, Psychosocial Aspects, High School Students

\section{Introduction}

In the age of globalization information and technology, the Internet has become a major factor in human knowledge development, organizational management, business activities and leisure activities. The Internet has become increasingly important to users in their everyday lives (Horrigan \& Rainie, 2006). It creates new ways for citizens to communicate, congregate and share information of a social 
nature (Kedem, 1999). People worldwide can communicate and respond to mutual needs instantly. Tele-conference accelerates the completion of a project. Open and distant learning provides worldwide learners with convenience and inexpensive educational opportunity, especially to low-income learners. Telemedicine allows medical specialists in Boston to diagnose and treat patients in California (Kedem, 1999). These are some benefits offered by the Internet which provides access to millions of resources worldwide and enables users to collect, store, transmit and retrieve information from other individuals, private companies, government agencies, academic institutions, research institutes, etc. Internet technology is rapidly and radically transforming the character of life and work. The changes driven by the Internet will have an enormous impact on the conduct of every aspect of our society business, government, education and private life (Kedem, 1999). On the other hand, the one purpose of this chapter, is to identify to interest in the issue of the effect of internet use on High School Students in Pattani on psychosocial (cited in Daraha Kanlaya, 2013).

\section{Internet usage statistics}

The widespread use of the Internet has been progressively increasing, covering users of all ages. According to Suler's study cited by Bob Affonso (1999), the number of people online worldwide in 1999 was 149 million, which was increasing at the monthly rate of $12 \%$. Internet Usage and World Population Statistics (2006) reported that as of June 30th, 2006, over 1.04 billion people used the Internet. According to an article titled "Are You Web Savvy" (Anonymous, 2005) for teenagers and young adults, the Internet is now a main source of information for what is "cool" and current in their world. From music, fashion, entertainment, sports, homework and instant communication with friends (Instant Messaging or IM), this new tool of communication is the most popular way among youth to "get connected". And according to the Internet Usage and World Population Statistics (2012) reported that people would use the Internet in all countries and usage in all regions of the world by June 30th, 2012. The top ten languages used in the web is English (26.8 percent), followed by Chinese (24.2 percent), Spanish (7.8 percent), Japanese (4.7 percent), Portuguese (3.9 percent), German (3.6 percent), Arabic (3.3 percent), French (3.0 percent), Russian (2.0 percent), Korean (82.2 percent) and Rest of language (17.8 percent) (Internet Usage and World Population Statistics, 2011).

\section{Internet and youth}

Youth use the Internet in large numbers and are highly computer-literate. According to the report of Lenhart et al. (2005): “Today's American teens live in a world enveloped by communications technologies." The number of teenagers using the internet has grown $24 \%$ in the past four years and $87 \%$ of those between the ages of 12 and 17 are online. Compared to four years ago, teens' use of the internet has intensified and broadened as they log on more often and do more things when they are online." The Internet has a big role for the youth and it affects for the youth in public high school and private Islamic high school in Pattani on psychosocial. The Internet is involved in some students' problem in 
skipping school to go to Internet cafes for playing online games, online chatting, browsing website where posing "sexy images" and accessing the Internet 24.25\%, 15.75\% and 40.25\%, respectively (Thai Research and Fund, 2008-2009).

The report complied for the Pew Internet \& American Life Project found that nearly nine out of 10 young people, (ages of 12 - 17), have online access, up from about three-quarters of young people in 2000 (Anonymous, 2005).

Based on the research of Lenhart et al. (2001) on teenager's life online, most of adolescents aged 12 to 17 use the Internet to send or read e-mails (92\%) and go online for fun (84\%). The other activities frequently done online by youth in this age bracket include visiting entertainment sites, getting news, playing or downloading games and listening to music. According to the Home Net study, teenagers are more likely to use the Internet to play games, to listen to music and to meet new people. They are most frequent Internet users compared to the adults who use the Internet as part of their jobs and to get employment-related information (cited in Kraut et al., 2002). Those online activities sound ordinary and potentially provide either good or bad effects on youth (cited in Daraha Kanlaya, 2013).

Many parents (87\%) believe the Internet helps their children in school and teens relied mostly on Internet sources for their school projects (71\%) (Lenhart, Rainie, \& Lewis, 2001). According to the Common Sense Media's National Attitude Poll in June 7, 2006, it was found that 77\% of parents saw the Internet as an important tool to help their kids learn. However, $85 \%$ of parents stated that the Internet, as the number one media instead of television, posed the greatest risk to their children among all forms of media. Though the parents' belief in their children's need in the Internet as benefits in discovering useful things and helping with schoolwork, "a national survey conducted by the Annenberg Public Policy Center in Washington found that majority of parents in computer households fear the Internet's influence on children, due particularly to its wide-open nature and interactivity" (Affonso, 1999). While being a large resource of useful information at the fingertips. On the other hand, the Internet also covers prevalence of sexually explicit material: sexually explicit dialogue and the use of imagery to simulate sexual activities. These "cybersex" activities have been drawing worldwide teenagers' attention online teens frequently communicate virtually with someone they have never met; almost one third of online teens (30\%) said they have chatted about meeting someone whom they have only met through the Internet; more than one third of these online teens (37\%) said they have received a link to sexually explicit content; one in four (27\%) said they have chatted online about sex with someone they have never met in person; and nearly one in five (19\%) reported knowing a friend who has been harassed or asked about sex online by a stranger (cited in Daraha Kanlaya, 2013).

According to Internet Addiction Statistics (2013), 18.3 percent of British students are pathological Internet users, whose excessive use of the Internet has caused them academic, social, interpersonal problems in addition to lower selfesteem (Niemz, Griffiths \& Banyard, 2005). In Norway, Internet users are at risk. 
Internet use is prevalence among young people regardless of gender. Psychologically and socially it has also affected them. Prolonged time spent on the Internet has caused them sleeping disorders and depression (Bakken, Wenzel, Götestam, Johasson, \& Øren, 2008). One study in Australia found that more video game addicts (among children) have suffered from depression ( 25 percent) and anxiety ( 15 percent) than moderate gamers.

In China, 95.8 percent of teenagers use the Instant Message, 9.8 percent of which can be classified as IM addicts (Huang \& Leung, 2009). 41 percent of self-selected online gamers play video games to escape and seven percent were at risk of developing psychological and behavioral disorders (Hussain \& Griffiths, 2009). In South Korea, some students suffered from mental disorder and weak social intelligence (Park, Kim, \& Cho, 2008). In fact, adolescents who play more than one hour of internet video games may exhibit more symptoms of ADHD (Anderson, Gentile, \& Buckley, 2007; Chan \& Robinnowitz, 2006).

In Thailand, primary school students spent 140.88 minutes watching television and 75.60 minutes surfing the Internet while high school and college students spent 163.04 and 94.01 minutes doing the same respectively. Primary school students viewed porn cartoons (17.31 percent), watched VCD (12.62 percent) and committed cybersex (8.38 percent), while the percentage of high school and college students doing the same were $30.25,39.27$ and 27.23 respectively (Amnuaykitcharoen, 2006: p. 22). Nakhonthan Amornwit, the Director of the Ramachitti Institution also concluded that children spend six to seven hours daily watching television (Amnuaykitcharoen, 2006), impelling the Ministry of Technology to enforce a gaming curfew to block all gaming servers between $10 \mathrm{pm}$ to $6 \mathrm{am}$.

In Thailand, according to the paper presented on "The Living Conditions of Children during 2004-2005", held by the Ramachitti Institution which was funded by the Thai Health Promotion Foundation and the Thailand Research Fund, it was found that primary school students spent 140.88 minutes and 75.60 minutes daily watching television and surfing the date. The main purpose in using the Internet among most high school student is for entertainment and WWW is the Internet service they most often used, followed by e-mail. The Internet opens their world of learning, providing them with greater knowledge, forming relationship with many new friends and improving their English.

In one secondary school in Chiengmai, internet addiction has psychosocially affected its students (Wanajak, 2011). They were estranged from peers and parents, and their academic performances declined. They also suffered from anxiety, depression and health problems like back pain, eye strain, hand corns, weight gain, weight loss as a result of prioritizing the internet.

\section{Pattani}

Pattani, 1055 kilometres away from Bangkok and located on the east coast of southern Thailand, is one of five southern border provinces of Thailand (Office of the Basic Education Pattani Area, 1, 2, 2006). It covers an area of approx- 
imately 1940.35 square kilometers or about 1,212,723 rais. It is administratively divided into 12 districts (Maung, Kok Poh, Ma Yor, Nhong Chick, Panareh, Sai Buri, Yarang, Yaring, Tung Yang Daeng, Mai Kaen, Kapor, Maelan), 115 subdistricts and 636 villages. Its local administrations consist of one provincial administration organization, 12 municipalities and 101 sub-district administration organizations. As an ancient prosperous kingdom densely populated by people of various races and religions since the past, Pattani consists of 639,503 people: 316,473 males and 323,030 females, with 138,236 households (data as of December 2004). Most people are Muslims (81.26\%) followed by Buddhists (17.83\%) and others $(0.91 \%)$ (Office of Information Technology and Communication Group of Pattani Office, 2005). It has been revealed that among off-school system people at the age of 15 - 59 years old in Pattani, there are 22,778 illiterate people: 9873 men and 12,905 women, who do not know, not recognize and are unable to read and write Thai. Among these people, 10,477 ones have never studied; 2050 ones finished only grade $1 ; 1822$ ones finished only grade $2 ; 1369$ ones finished only grade 3; 2961 finished only grade 4; 911 ones finished only grade 5; 2505 ones finished only grade 6; 228 ones finished grade 7; and 445 ones finished grade 8 .

According to the National Education Act 1999 and the new structure of the Ministry of Education in 2003, Pattani educational management is categorized into three forms: in-system, off-system and dispositional. There are five organizations responsible for Pattani education management: Office the Basic Comission Pattani Education Area 1, Office the Basic Comission Pattani Education Area 2, the Vocational Education Office, the Local Educational Administration Office, the Off-school Learning Center. Pattani includes sixty-seven high schools; nine public high schools and fifty-eight Islamic private high schools (where Islamic studies are in the curricula) (Office of the Basic Education Pattani Area, 1, 2, 2006).

All of them have Internet access. Moreover, most of them, especially mediumsized to large-sized ones are surrounded by Internet cafés. They offer great assistance to students for their assignments, specifically when the number of computers at school is not enough and when they do not go to school. Additionally, John F. Kennedy Library of Prince of Songkla University Pattani Campus offers a modern and large IT zone. On the other hand, these Internet facilities created problems among the students. Some of the students' problems relating to the Internet including skipping classes to go to the Internet cafés for playing online games, online chatting, browsing websites where "sexy" images are available. Some of them spend over a half of the night going online and their bedtime is after midnight or nearly dawn. Consequently, they feel drowsy and sleepy in class. The number of at-risk youth in both public and private schools in the province Pattani, Thailand has increased drastically. They have spent the internet 169.71 minutes per day (Thai Research and Fund, 2008-2009). While the Internet is a cause of those students' misbehaviours, some improved in their academic per- 
formances because of learning useful information relating to their subjects; for example, free online lessons and exercises. These indicate that the Internet affects high school students in Pattani in various aspects.

According to Tapkila (1997), Thai high school students consider the Internet a beneficial tool to expand their knowledge and making them "up-to-date". These students often use the internet for entertainment, surfing and emailing. The technology, according to them, opened their world by providing them greater knowledge, new friendships and improved English (cited in Daraha Kanlaya, 2013).

\section{In the Southern most of Thailand and Pattani}

Research that has been conducted by the Pattani Campus, Prince of Songkla University revealed that children in Pattani, Yala and Narathiwat liked to play games in the internet (Kai-Nunna Phirakan, 2012).

Kai-Nunna Phirakan, Phetmongkon Dootsadee and Maitreephun Warapark. (2011) of Faculty of Communication Sciences and PSU, Pattani reported the behaviour of children and young people in the southern provinces with regards to the internet use. Children and young people very often played online games at least eight hours a day.

While the problem of online game addiction is aggravating, only few parents were aware of it (Kai-Nunna Phirakan, 2012). Phirakan concluded that the parents lack the skills to manage and solve this problem; in fact, they believed this issue falls under the school's responsibility (Kai-Nunna Phirakan, 2012). According to Kai-Nunna Phirakan (2012), students who skipped school were brought by their parents to play games at Internet cafes themselves. Often these parents justified that they have to work and their children had to commute to school by bus. Parents also claimed that they do not know what their children do daily (Kai-Nunna Phirakan, 2009).

Phirakan's study found students in the southernmost of Thailand skipped school to play game at Internet cafes near schools. This has affected their studies, particularly those in lower secondary. Many students could not finish their studies despite community's observation. This community are only connected to the school by phone and furthermore, the students' parents did not realize this problem, let alone solve it (Kai-Nunna Phirakan, 2009; Kai-Nunna Phirakan et al., 2011).

In Thailand, children and youth play games for average 9.20 hours per week while the children and youth in the southernmost play games for average 13.23 hours per week. In primary school, they play for 9.09 hours per week while in lower high school students play around 18.09 hours per week. Upper high school students play games around 10.09 hours per week, causing them to skip schools and eventually, unable to finish their studies. This happened not only in public high schools but also in private Islamic high schools. In Internet cafes, they are exposed to drug addiction. This phenomenon is called Alprazolam and it is causing them to lose their lives (Kai-Nunna et al., 2011). In Pattani, the students watch VDO/VCD (high schools on upper level, 66 per cent and lower level, 43 
percent). They also watch cartoons (11.50 percent), VCD (13.00 percent), pornographic websites (15.75 percent), clips (21.05 percent) and surf the internet (40.25 percent) (Thai Research and Fund, 2008-2009).

\section{Statement of problem}

The growth of internet use has raised the number of students and adolescents at risk of being psychosocially affected (Niemz, Griffiths, \& Banyard, 2005). The excessive use of the technology had caused academic, social and interpersonal problems and addicted students were found to have lower self-esteem than other students. Pattani, a southern border province of Thailand, has both public and private high schools where religious studies are included and all of them have internet access.

According to the National Education Act 1999 and the new structure of the Ministry of Education in 2003, Pattani educational management is categorized into three forms: in-system, off-system and dispositional. Five organizations are responsible for Pattani education management: Office the Basic Education Commission Pattani Area 1, Office the Basic Education Commission Pattani Area 2, the Vocational Education Office, the Local Educational Administration Office, the Off-school Learning Center. Pattani has sixty-seven high schools: nine public high schools and fifty-eight Islamic private high schools (where Islamic studies are in the curricular) (Office of the Basic Education Pattani Area, 1, 2, 2006).

Pattani, a southern border province of Thailand, has both public and private high schools where religious studies are included and all of them have internet access. In Pattani high schools, students use the Internet around 169.71 minutes per day. Most of the schools (particularly the medium and large ones) are surrounded by Internet cafés, which offer "alternatives" for students to do their assignments in when they miss to catch the limited number computers in school, or simply when they skip school. While some educational institutions like the John F. Kennedy Library of Prince of Songkla University Pattani Campus offers a modern and large IT zone, these Internet facilities may create problems among the students. Problems relating to Internet use among students include absenteeism to visit the internet cafe, a place they get to play online games (24.5 percent), online chatting and browsing pornography (40.25 percent). Some of them were online most of the night and only sleep near dawn, causing them to feel sleepy in class in the following day. These at-risk adolescents unfortunately, are increasing in both public and private schools in Pattani (Thai Research and Fund, 2008-2009).

While the internet causes students' misbehaviours, it also allows them to learn useful information on their subjects, improving further their academic performances. For example, these students can benefit from free online lessons and exercises. All these indicate that the internet has affected high school students in Pattani in various psychosocial.

Even though, mostly populated by Muslims, Pattani has two types of high school: the general public high school and the private Islamic high school. With equal hours of secular subjects, students of both high schools are differentiated 
by the curricular of their religious studies. Those in private Islamic learn Islamic spiritual practices and morals in addition. On the other hand, those in public schools are oriented towards secular studies. As the Basic Education Core Curriculum aims to enhance a learner's capacity in all respects (physical strength, knowledge and morality), the internet becomes a great learning tool (Office of the National Education Commission Office of the Prime Minister, Thailand, 1999) to conduct wellbeing of students.

Thailand's three southernmost provinces are now facing this apprehensive situation that threatens the nation's security (U.S. Department of State Diplomacy in Action, 2013). Many youth are lured to commit crimes intentionally and unintentionally and good education with community cooperation is a long-term practical resolution to this problem. Discovering this underlying issue can greatly benefit the government in making policies and others concerned about the well-being of youth in this province.

At the same time, the researcher noticed that some students who use the Internet as a learning tool perform their assignments well and are confident to share their knowledge. This paradox impelled the researcher to conduct a more indepth study on this issue.

\section{Research questions}

What would be the social work interventions that can be recommended in order to overcome some of the psychosocial problems of internet use among these students?

\section{Research objectives}

To recommend some workable social work interventions that are workable for students who are affected by this issue.

\section{Methodology}

The research is done through qualitative approach to collect through extensive interviews, casual conversation formal and informal observations and analyzes the research data. In depth portraits of a small number of five school students, five school teachers, five school parents, two policemen, two communities, two owner Internet cafes and two directors from primary public school and public high school and focus group discussions: the parents and the general people from Muang district, Kokpho district, Yaring District and Saiburi in 2007. Due to the violent situation occurs since 2004, the researcher considered from the safest area, the school size or the number of students and the capability to provide the students both with sufficiently effective Internet access, Internet courses in 2007 would however provide and support much fuller access to their views across arrange of the issues of problem. A total of interviews semi-structure interviews with open-ended questions were conducted for the purpose of study. All interviewers were audio tape-recorded and informal conservations, In this study, the data were gathered to learn of each group. After that, the data obtained from these cases were analyzed.

Summary of High School students Internet Effects 


\section{Academic Effects}

Many of communities viewed that the high school students loved to search the knowledge and information from the Internet. Additionally, their positive way of using the Internet for searching information for their school assignments. It could contribute to their improved academic performances. This was also supported by their teachers' discovery of their students' improved cognitive skills and performances.

Additionally, new Thai educational system more emphasizes on integrated learning both via technology and traditional and community knowledge. Text-books and blackboards are not dominating teaching materials anymore. The high school teachers' discovery of great differences in cognitive skills and performances between their Internet using students and non-Internet using students, the Internet helped to enlarge their students' knowledge, widen their views and improve their comprehensions in lessons. This resulted in their better class participations, informative discussions and well-done assignments. This discovery agreed to many studies which have indicated that students can have better retention and understanding of a given topic by learning through the Internet (Rojem, 2002).

\section{Effects psychosocial}

The present study discovered that the high school students in Pattani spent many hours of Internet. They tent to spend less time with their families when they devoted more time to the Internet. This finding supports Sanders et al. (2002) who discovered that low Internet users (less than one hour a day) had significantly relationships with their mothers and peers than high Internet users (more than two hours a day). A report compiled for the PEW Internet \& American Life Project found that out of $87 \%$ of teens who used the internet in the United States, $51 \%$ were online daily, $89 \%$ used the tool to send or read e-mails, $81 \%$ played games online, $69 \%$ carried out homeworks and $43 \%$ shopped online. Such heavy usage has caused college students to be depressed, physically ill, lonely, anxious, introverted, schizotypy and autistic (Chen \& Peng, 2008; Romano, Osborne, Truezoli, \& Reed, 2013). Thus, the Internet caused them to play online games. It affected them aggressive, furious, moody, anxiety. This findings supported Chen \& Peng, 2008; Wanajak, 2011; Romano, Osborno, Truzoli \& Reed, 2013.

However, different from other studies (UCLA, 2003), cyber communications like e-mailing, instant messaging and online chatting were not the top online activities, and it found that email is the most popular way to use the Internet for discussions on any topic with friends, over fifty percent of them preferred using the phone, followed by the traditional face-to-face interaction; while e-mailing and instant messaging were used by a very tiny minority of them. The phone, especially a mobile one, plays a great role on their creation of relationship with their friends. They most often called on the phone to communicate with their friends in all subjects including a quick discussion with a friend they saw regularly, a private discussion with someone that they did not want anyone else to find out about and a discussion with a friend about something really serious or 
important. Not only calling, they also used the phone to send their friends text messages.

In cultural context, adolescents in the western or American culture are less socially affected by internet use (Cárdenas et al., 2000). In addition to their belief in adults' advice, economic reasons, limitation of Internet use and attitudes towards the Internet, the cooperation between the government and the public had also protected these youths from negative social effects of the Internet. In supporting its students' technological learning and development, the government did not neglect the harmful side of the Internet. As the cyber world was enormously free, the government had launched a policy on youth's access to websites.

Ministry of Information Communication and Technology is responsible to monitor web page contents and is authorized to block any harmful page. In accordance with the policy, schools must also monitor their students' Internet use and limited them from accessing inappropriate websites. Additionally, Internet cafés owners must set strict rules of forbidding their customers from visiting porn sites. The police must also monitor the running of Internet cafés. This cooperation partly resulted from teachers', Internet café entrepreneurs' and the police's high morals and ethics.

\section{Result}

According to the opinions towards the psychosocial aspects from using internet by high school students in Muang, Pattani province. The study found that internet use has affected the high school students both socially and psychologically. Students who spent more than eight hours a day on the internet were more likely to neglect their responsibilities. They also had relationship problems with their parents and family members. They tend to be aggressive, easily upset, moody and sleepy in class. Additionally, they were also likely to skip meals, got depressed and exhibited poor physical health like having back, neck, wrist and finger pains. Their academic performance also declined. However, the internet use had also helped students gained new knowledge that enabled them to make informed decision. Ministry of Education, Ministry of Culture, Ministry of Information and Technology and Ministry of Social Development and Human Security must collaborate and blocked websites that enhanced negative behavior. Some opined that students be supervised when using the internet and at the same time, be regulated on the time they should spend on the technology. School social workers could play a role in helping high school students use the internet appropriately. Through the Students' Care and Support System (SCSS) that was already introduced in schools, social workers could be more effective in solving problems that arose from internet use among high school students.

\section{Focus group discussions}

According to the opinions towards the psychosocial aspects from using internet by high school students in Muang, Pattani province. The study revealed that 
the internet had caused the students in psychsocial and academic performance. The students lacked of responsibilities and they were aggressive and moody easily. The parents must limitation for use the internet properly. Ministry of Social Development and Human Security and school must block the immoral websites and it was necessary to have social work intervention to overcome to school, they could collaborate with the parents, teachers, psychologists, the communities and stakeholders to conduct wellbeing of students and the sample of the stakeholders commented were as follows:

"Positively, it is excellent as a source of knowledge and information. To prevent harmful effects from the Internet, basically, children's Internet hours should be limited. In the social worker's view, it is good. However, social workers need to jointly work more with teachers. Parents need to know how to handle modernly with their children's Internet use. Students should be always instructed on appropriate and disciplined use of the Internet".

"Absolutely, yes. It was proposed to the government that school should have a social worker; however, they claim that there are not enough budgets to support social workers for all schools across the country. There is not financial support for this, but we have human resource as teachers. Thus we train teachers to be able to do social work at their schools".

\section{Recommendations}

The findings of this study can be useful for schools, stakeholders, Ministry of Education, Ministry of Culture, Ministry of Information and Technology and Ministry Social Development and Human Security to plan a policy to solve the problems of Internet addiction among students. The informants proposed to have social workers in schools to solve this issue.

Data from the four main focus of the current research were sifted in order to provide the basis for the construction of an Enhancement Model of SCSS for the Pattani Province of Thailand, in hope to promote the well-being of high school students in this domain.

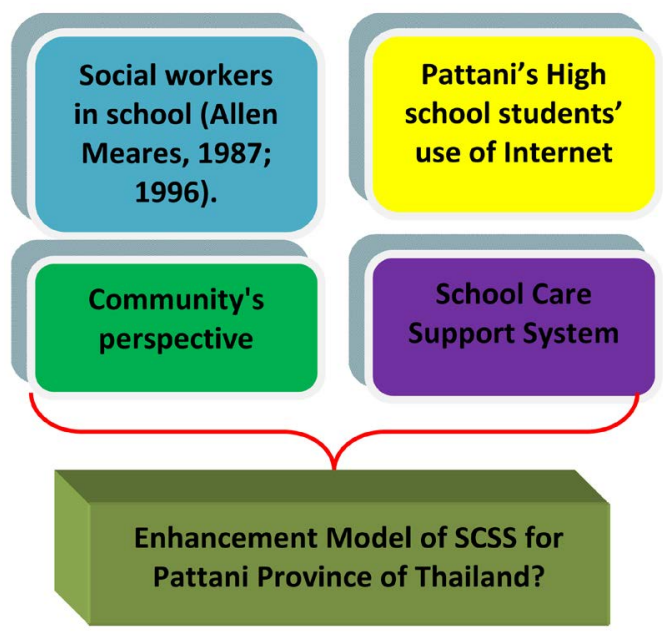


The Student Care and Support System (SCSS) is a vivid tool. A social worker in a school is the key person who cooperates with students' parents and relevant teachers, principals and the community in order to encourage the development of students' desirable behaviours (Allen-Meares, 1987; Allen-Meares et al., 1996). Additionally, the social workers also help to abate the students risky behaviors of internet addiction.

\section{The school social work model}

School social work can serve as a model to address problems of excessive internet use among high school students. This school-based model necessitates the involvement of more social workers in schools. It is a challenging for the Thai government to provide more trained school social workers in order to solve the psychosocial problems that have plagued Thai youth today. These social workers could socialize the youth and helped teachers to understand the youth behavioral, physical and emotional needs via external effects.

\section{Conclusion}

The internet is the big roles in the lives of the youth and students. The researcher studied qualitative on various groups and focus group discussions for guiding the government to find the ways for protect the harmful injurious for the youth's well-being. The great thing, many of them proposed that it should have the social work module to support collaboratively for better youth in Pattani and other provinces in Thailand generally, the social intervention, the social worker will have the opportunity to work with school teachers in school to address the social and educational issues faced by school children and Student Care and Support System (SCSS) program had been introduced in Pattani.

\section{Areas for further research}

As the Internet plays increasingly great roles in the lives of present adolescents, there should be a deeper study on individual aspects: psychosocial and academic performance. Only survey study is not sufficient. The study should be designed as a comparison between two test groups. There should be a comparison between the high school students learning Internet-based lesson and those with only traditional learning method. Additionally, comprehensive and deeper research on Internet effects is based on various case studies, for example, province, region, economic status, etc.

\section{Conflicts of Interest}

The author declares no conflicts of interest regarding the publication of this paper.

\section{References}

(2006). Internet Usage and World Population Statistics. Internet World Stats. http://www.internetworldstats.com/stats.htm

(2011). Internet Usage and World Population Statistics. Internet World Stats. http://www.internetworldstats.com/stats.htm 
(2012). Internet Usage and World Population Statistics. Internet World Stats. http://www.internetworldstats.com

(2013). Internet Addiction Statistics-Facts, Figures, \& Numbers. http://www.techaddiction.ca/internet addiction statistics.html

Affonso, B. (1999). Is the Internet Affecting the Social Skills of Our Children? University of Nevada.

https://mardhikaf.wordpress.com/2009/05/04/is-the-internet-affecting-the-social-skills -of-our-children

Allen-Meares, P. (1987). A National Study of Educational Reform: Implications for Social Work Services in Schools. Children \& Youth Services Reviews, 9, 207-219. https://doi.org/10.1016/0190-7409(87)90031-4

Allen-Meares, P., Washington, R. O., \& Welsh, B. L. (1996). School Social Work Services in Schools (2nd ed.). Allyn and Bacon.

Amnuaykitcharoen, A. (2006). Living Conditions of Thai Children during 2004-2005. Matichon, p. 22. http://thai.tourismthailand.org/about-thailand/fast-facts

Anderson, C. A., Gentile, D. A., \& Buckley, K. E. (2007). Violent Video Game Effects on Children and Adolescents: Theory, Research, and Public Policy. Oxford University Press. https://doi.org/10.1093/acprof:oso/9780195309836.001.0001

Anonymous (2005). Youth Are Leading the Transition to a Fully Wired and Mobile Nation.

Bakken, I. J., Wenzel, H. G., Götestam, K. G., Johansson, A., \& Øren, A. (2008). Internet Addiction among Norwegian Adults: A Stratified Probability Sample Study. Scandinavian Journal of Psychology, 50, 121-127. https://doi.org/10.1111/j.1467-9450.2008.00685.x

Cárdenas, C., Jasper, S., Parton, K., Rose, J., \& Swartz, L. (2000). The Internet's Effect on Personal Lives.

Chan, P. A., \& Rabinowitz, T. (2006). A Cross-Sectional Analysis of Video Games and Attention Deficit Hyperactivity Disorder Symptoms in Adolescents. Annals of General Psychiatry, 5, 16-27. https://doi.org/10.1186/1744-859X-5-16

Chen, Y. F., \& Peng, S. S. (2008). University Students' Internet Use and Its Relationships with Academic Performance, Interpersonal Relationships, Psychosocial, Adjustment, and Self-Evaluation. CyberPsychology \& Behavior, 11, 467-469. https://doi.org/10.1089/cpb.2007.0128

Daraha, K. (2013). The Effect of Internet Use on High School Students in Pattani Province. Procedia Social and Behavioral Sciences, 91, 241-256. https://doi.org/10.1016/j.sbspro.2013.08.422

Horrigan, J., \& Rainie, L. (2006). The Internet's Growing in Life's Major Moments (p. 202).

Huang, H., \& Leung, L. (2009). Instant Messaging Addiction among Teenagers in China: Shyness, Alienation, and Academic Performance Decrement. Cyber Psychology \& Behavior, 12, 675-679. https://doi.org/10.1089/cpb.2009.0060

Hussain, Z., \& Griffiths, M. D. (2009). Excessive Use of Massively Multi-Player Online Role-Playing Games: A Pilot Study. International Journal of Mental Health and Addiction, 7, Article No. 563. http://link.springer.com/article/10.1007\%2Fs11469-009-9202-8 https://doi.org/10.1007/s11469-009-9202-8

Kai-Nunna, P. (2009). Find the Activities Construct the Realization for Students and Parents for Solving the Children Game Addiction. http://w08.psu.ac.th/node/5154

Kai-Nunna, P. (2012). Online Games, Appropriate Guidelines to Protect Young in Southernmost, Thailand. http://w08.psu.ac.th/node/5154

Kai-Nunna, P., Phetmongkon, D., \& Maitreephun, W. (2011). Prince of Songkla Univer- 
sity Research Reveals the Problem of Game Addiction in Children and Youths in the Deep South. http://www.healthygamer.net/information/news/8398

Kedem, C. (1999). The Social Impact of the Internet on Our Society. https://www.math.umd.edu/ bnk/UMUC/project.htm\#Intro

Kraut, R., Kiesler, S., Boneva, B., Cummings, J., Helgeson, V., \& Crawford, A. (2002). Internet Paradox Revisited. Journal of Social Issues, 58, 49-74. http://onlinelibrary.wiley.com/doi/10.1111/1540-4560.00248/abstract https://doi.org/10.1111/1540-4560.00248

Lenhart, A., Madden, M., \& Hitlin, P. (2005). Teens and Technology: You Are Leading the Transition to a Fully Wired and Mobile Nation.

Lenhart, A., Rainie, L., \& Lewis, O. (2001). Teenage Life Online: The Rise of Instant-Message Generation and the Internet's Impact on Friendships and Family Relationships. http://www.pewinternet.org/report display.asp? $\mathrm{r}=36$

Niemz, K., Griffiths, M., \& Banyard, P. (2005). Prevalence of Pathological Internet Use among University Students and Correlations with Self-Esteem, the General Health Questionnaire (GHQ), and Disinhibition. CyberPsychology \& Behavior, 8, 562-570.

https://doi.org/10.1089/cpb.2005.8.562

Office of Information Technology and Communication Group of Pattani Office (2005). Summary of Pattani 2005.

Office of the Basic Education Pattani Area, 1 (2006). Data of Private Schools in Article 15 (1) of Academic Year 2006.

Office of the Basic Education Pattani Area, 2 (2006). Data of Numbers Students in (Private) Primary and High Schools.

Office of the National Education Commission Office of the Prime Minister, Thailand (1999). National Education Act B.E. 2542 (1999) and Amendments (Second National Education Act B.E. 2545 (2002). The Academy Books.

Park, S. K., Kim, J. Y., \& Cho, C. B. (2008). Prevalence of Internet Addiction and Correlations with Family Factors among South Korean Adolescents. Adolescents, 43, 895-909. http://www.ncbi.nlm.nih.gov/pubmed/19149152

Rojem, K. (2002). The Impact of the Internet on Education.

Romano, M, Osborne, L. A., Truzoli, R., \& Reed, P. (2013). Differential Psychological Impact of Internet Exposure on Internet Addicts. PLOS ONE, 8, e55162. https://doi.org/10.1371/journal.pone.0055162

Sanders, C. E., Field, T. M., Diego, M., \& Kaplan, M. (2002). The Relationship of Internet Use to Depression and Social Isolation among Adolescents. Adolescence, 35, 237-242.

Tapkila, K. (1997). The Internet Users' Behaviors of Upper Secondary Education Students in Schools Participating in Schoolnet Thailand. Master Thesis, Chulalongkorn University, Thailand, Srinakarintaraviroad University.

Thai Research and Fund (2008-2009). Child Watch Thai. Ministry of Social Development and Human Security.

U.S. Department of State Diplomacy in Action (2013). 2013 Country Reports on Human Rights Practices. http://www.state.gov/j/drl/rls/hrrpt/2013

UCLA Internet Project (2003). Surveying the Digital Future, Year 3. UCLA Center for Communication Policy, University of California. http://www.ccp.ucla.edu

Wanajak, K. (2011). Internet Use and Its Impact on Secondary School Students in Chiangmai, Thailand. Unpublished Doctoral Thesis, Edith Cowan University. 